\title{
Korelasi Sifat-Sifat Agronomi dengan Hasil dan Kandungan Antosianin Padi Beras Merah
}

\section{Correlation of Agronomic Characters with Yield and Anthocyanin Content of Brown Rice}

\author{
Hafidh Prabowo ${ }^{1)}$, Djati Waluyo Djoar ${ }^{2)}$, Pardjanto ${ }^{2)}$
}

\begin{abstract}
Brown rice is a type of rice can be grown on land that is less water (upland). Brown rice has anthocyanin as an antioxidant. The purpose of this study was to identify brown rice agronomics characters that can be used as selection criteria to obtain brown rice which high anthocyanin. The experiment was conducted at the greenhouse of Agriculture Faculty, UNS using completed randomized block design consisting of 5 local varieties namely Mandel Wonogiri, Segreng Gunung Kidul, Segreng Boyolali, Segreng Wonogiri 1, and Segreng Wonogiri 2. Analysis of the data using the model Singh and Chaudhary (1979) are displayed in the form of a matrix correlation. Anthocyanin assays using the differential $\mathrm{pH}$ test method. The results showed that there was no difference between the anthocyanin content of varieties, but there is a tendency Segreng Boyolali varieties containing anthocyanins and Mandel Wonogiri higher. In general, varieties tested showed different potential yield, except Mandel Wonogiri varieties have low yield. The character of the total number of tillers, panicle length, and number of panicles per hill showed a strong correlation coefficient with the results. Plant height, number of panicles per hill, and the weight of 1000 seeds showed a high correlation coefficient with anthocyanin content.
\end{abstract}

Keywords : anthocyanin, brown rice, genetic and phenotypic correlations

\section{PENDAHULUAN}

Beras (Oriza sativa L.) memiliki berbagai macam varietas. Seperti beras putih, beras coklat, beras merah, beras hitam, beras ketan putih, dan beras ketan hitam. Beras ketan putih dan ketan hitam memiliki rasa manis dan lengket, berbeda dengan beras merah dan beras hitam yang memiliki rasa agak manis dan pera, maupun beras putih yang memiliki rasa netral sehingga cocok dimakan bersama lauk pauk.

Sampai saat ini, sebagian besar masyarakat belum mengetahui manfaat beras merah. Sebenarnya beras merah mengandung senyawa antosianin yang mampu mencegah berbagai penyakit, seperti kanker, kolesterol, dan jantung koroner. Beras merah merupakan sumber protein dan mineral, seperti selenium yang dapat meningkatkan daya tahan tubuh, serta sumber vitamin B yang dapat menyehatkan selsel syaraf dan sistem pencernaan. Beras merah juga memiliki kandungan serat yang tinggi sehingga dapat mencegah konstipasi (Fitriani 2006).

Padi beras merah banyak ditanam terutama di Asia Selatan, Italia, Yunani, dan Amerika Serikat. Di Cina, beras berwarna dipercaya sebagai makanan sehat, tetapi belum ada penelitian yang membuktikan bahwa mengonsumsi beras merah dan hitam

\footnotetext{
1) Undergraduate Student of Study Program of Agrotechnology, Faculty of Agricuture University of Sebelas Maret (UNS) in Surakarta.

${ }^{2)}$ Lecturer of Study Program of Agrotechnology, Faculty of Agriculture University of Sebelas Maret (UNS) in Surakarta.
}

Contact Author: parjanto_uns@yahoo.co.id berpengaruh pada penyakit athero-sklerosis atau pembuluh darah (Ling et al. 2001). Beberapa jenis beras merah lokal di daerah Amerika Utara memiliki kadar protein antara $10-14 \%$, kadar lemak antara 2 $3 \%$ serta kadar karbohidrat yang tinggi, yaitu diatas $70 \%$ (Gealy dan Bryant 2009). Kadar protein beras merah lebih tinggi dibandingkan dengan beras putih pecah kulit yang memiliki kandungan protein sekitar $7 \%$, bahkan beras putih yang telah mengalami proses penggilingan hanya mengandung $5 \%$ protein (Heinemann et al. 2005).

Warna merah pada beras dipengaruhi oleh senyawa antosianin (Maekawa 1998). Warna merah dari lapisan bekatul ini berasal dari antosianin yang bersifat antioksidan (Perera dan Jansz 2000). Senyawa antosianin merupakan pigmen merah yang terdapat pada lapisan beras (perikarp dan tegmen), yang juga terdapat pada setiap bagian gabah (Chang dan Bardenas 1965). Selain pada padi-padian, antosianian juga terdapat pada buah-buahan, kacangkacangan, serealia, sayuran dan beberapa bahan pangan lainnya (Suda et al. 2003). Berdasarkan penelitian Xia et al. (2006), beras merah dan beras hitam mengandung antioksidan jenis antosianin yang dapat digunakan dalam terapi hipolipidemik, menstabilkan pembentukan plak atherosklerosis dan meningkatkan level antioksidan pada kelinci yang diberi diet tinggi kolesterol.

Beras merah merupakan jenis padi gogo yang dapat ditanam di daerah kurang air. Beberapa wilayah di Kabupaten Boyolali, Gunung Kidul, dan Wonogiri mengalami kekeringan apabila musim kemarau. Maka dari itu, banyak petani di daerah tersebut menanam padi beras merah karena dapat bertahan hidup dan tumbuh dalam kondisi yang kurang air. 
Berdasarkan ketiga tempat tersebut, terdapat beberapa varietas lokal padi beras merah seperti varietas Mandel Wonogiri, Segreng Gunung Kidul, Segreng Boyolali, Segreng Wonogiri 1, dan Segreng Wonogiri 2. Kristamtini dan Purwaningsih (2009) dalam penelitiannya menjelaskan bahwa ada lima jenis padi beras merah lokal asal DIY, yaitu Mandel (Gunung Kidul), Segreng (Gunung Kidul), Cempo merah (Sleman), Saodah merah (Bantul) dan Andel merah.

Varietas padi yang menjadi pilihan saat ini adalah padi tipe baru (PTB) yaitu tipe padi yang dirumuskan oleh IRRI (Khush 1995; 1999). Prototipe PTB memiliki sifat penting seperti jumlah anakan produktif sedang (8-10/rumpun), jumlah gabah per malai bernas (200-250 gabah/malai), tinggi tanaman sedang $(80-100 \mathrm{~cm})$, bentuk daun tegak berwarna hijau tua, berumur sedang (100-120 hari), perakaran vigor dan dalam, tahan OPT. Sifat-sifat ini sangat penting untuk mencapai potensi hasil yang tinggi.

Kelima varietas tersebut belum diketahui potensi hasil dan kandungan antosianin. Berdasarkan permasalahan tersebut, untuk mendapatkan varietas padi beras merah yang memiliki potensi hasil dan kandungan antosianin tinggi, maka diperlukan proses pemuliaan tanaman melalui proses seleksi.

Seleksi tanaman merupakan suatu metode pemuliaan tanaman yang berguna untuk mendapatkan genotipe unggul. Terdapat berbagai macam karakter tanaman. Suatu karakter dapat digunakan sebagai kriteria seleksi apabila terdapat hubungan yang nyata antara suatu karakter dengan karakter yang dituju. Hubungan yang nyata antara karakter hasil dengan karakter komponen hasil tanaman padi beras merah dapat diketahui dengan menggunakan analisis korelasi (Aryana 2009). Selain itu, Musa (1978) dalam Aryana (2009) mengatakan bahwa pengetahuan mengenai korelasi antar karakter agronomi suatu tanaman dengan daya hasil memiliki peranan penting untuk seleksi simultan pada beberapa karakter.

Pemuliaan tanaman berjalan dinamis dan terus berlanjut. Bersifat dinamis karena adanya keadaan lingkungan yang terus berubah dari masa kemasa. Sebagai contoh sejalan dengan perkembangan jaman, selera konsumen atas bahan makanan berbeda. Hal ini mendorong agar tanaman dan lingkungan dapat bekerja secara optimal, sehingga pemuliaan tanaman terus selalu berkembang. Terus berlanjut berarti kegiatan pemuliaan berjalan secara berkesinambungan. Gepts dan Hancock (2006) dalam penelitiannya mengatakan bahwa pemuliaan merupakan ilmu terapan yang multidisiplin, dengan menggunakan beragam ilmu lainnya, seperti genetika, sitogenetik, agronomi, botani, fisiologi, patologi, entomologi, genetika molekuler, biokimia, statistika dan bioinformatika.

Salah satu tujuan dari pemuliaan tanaman adalah mendapatkan varietas padi yang berumur genjah. Padi umur genjah dapat meningkatkan intensitas tanam dan pemanfaatan lahan. Padi berumur genjah mempunyai nilai ekonomi tinggi karena pertumbuhannya cepat, mampu berkompetisi dengan gulma dan memerlukan air relatif sedikit selama pertumbuhan, sehingga mengurangi biaya pengelolaan (Khush 1995, Khush et al. 2001). Penelitian ini bertujuan untuk mengkaji korelasi sifat-sifat agronomi dengan daya hasil dan kandungan antosianin.

\section{METODE PENELITIAN}

Penelitian ini menguji 5 varietas lokal padi beras merah dari daerah Boyolali, Gunung Kidul, dan Wonogiri dengan nama varietas Segreng Boyolali, Mandel Wonogiri, Segreng Gunung Kidul, Segreng Wonogiri 1 dan Segreng Wonogiri 2. Menggunakan Rancangan Acak Kelompok Lengkap (RAKL) dengan 5 ulangan (blok).

Penanaman dilakukan pada media tanam dalam polybag (campuran tanah dengan pupuk kandang). Setiap polybag berisi 2 tanaman. Pemupukan dilakukan dengan $200 \mathrm{~kg} \mathrm{ha}^{-1}$ urea, $100 \mathrm{~kg} \mathrm{ha}^{-1} \mathrm{SP}$ 36 , dan $150 \mathrm{~kg} \mathrm{ha}^{-1} \mathrm{KCl}$. Variabel-variabel yang diamati adalah tinggi tanaman, total jumlah anakan, jumlah anakan produktif, panjang malai, jumlah malai per rumpun, berat 1000 biji, berat gabah per rumpun, jumlah gabah per malai, dan kandungan antosianin. Pengamatan kadar antosianin menggunakan metode uji pH diferensial (Giusti dan Wrolstad 2001), ditera pada panjang gelombang A510-A700 untuk setiap larutan buffer $\mathrm{pH} 1,0$ dan $\mathrm{pH} 4,5$. Hasil analisis dibaca dengan menggunakan spektrofotometer. Analisis data dilakukan dengan menggunakan analisis varian (Anova) dan DMRT. Analisis Korelasi antar karakter dengan menggunakan analisis kovarian model Singh dan Chaudhary (1979) sebagaimana pada Tabel 1.

Tabel 1. Analisis Kovarian Rancangan Acak Kelompok

\begin{tabular}{llll}
\hline Sumber Keragaman $(\mathrm{SK})$ & Derajat bebas $(\mathrm{db})$ & Kovarian & Nilai Harapan Kovarian \\
\hline Kelompok & $\mathrm{r}-1$ & - & - \\
Genotipe & $\mathrm{g}-1$ & $\mathrm{~K} 2$ & $\mathrm{Kov}_{\mathrm{e}}+\mathrm{r} \mathrm{Kov}_{\mathrm{g} . \mathrm{xy}}$ \\
Galat & $(\mathrm{r}-1)(\mathrm{g}-1)$ & $\mathrm{K} 1$ & $\mathrm{Kov}_{\mathrm{e} . \mathrm{xy}}$ \\
\hline Total & $\mathrm{rg}(-1)$ & - & - \\
\hline
\end{tabular}

Tabel 1 merupakan metode korelasi genotipe dan fenotipe antar dua karakter, dengan :

$$
\begin{gathered}
\frac{K 2-K 1}{r} \\
K o v_{f . x y}=K o v_{g . x y}+K o v_{e . x y}
\end{gathered}
$$

$\mathrm{K} 1=$ Jumlah hasil kali kuadrat tengah galat karakter $x$ dengan $y$.

K2 = Jumlah hasil kali kuadrat tengah genotipe karakter $\mathrm{x}$ dengan $\mathrm{y}$.

Nilai koefisien korelasi fenotipe dan genotipe antara karakter $\mathrm{x}$ dan $\mathrm{y}$ dihitung dengan rumus sebagai berikut : 


$$
r_{p}=\frac{\text { Kov }_{p . x y}}{\sqrt{\sigma_{p}^{2} x \cdot \sigma_{p}^{2} y}} \quad r_{g}=\frac{K_{o v_{g . x y}}}{\sqrt{\sigma_{g}^{2} x \cdot \sigma_{g}^{2} y}}
$$

dengan:

$r_{p}=$ koefisien korelasi fenotipik

$r_{g}=$ koefisien korelasi genotipik

$\mathrm{Kov}_{\mathrm{p} . \mathrm{xy}}=$ peragam (kovarian) fenotipik antar karakter $x$ dan $y$

Kov $_{\text {g.xy }}=$ peragam (kovarian) genotipik antar

$\sigma^{2} \mathrm{p} \quad$ karakter $\mathrm{x}$ dan $\mathrm{y}$

$\sigma_{\mathrm{p}}^{2} \mathrm{y} \quad=$ ragam fenotipik karakter

\section{HASIL DAN PEMBAHASAN}

\section{Pertumbuhan dan Hasil}

Rata-rata dan hasil uji DMRT dari variabel-variabel pertumbuhan dapat dilihat pada Tabel 2. Varietas Mandel Wonogiri memiliki rata-rata tinggi tanaman paling tinggi dan berbeda nyata dengan varietas lain. Hal ini serupa dengan penelitian Kristamtini dan Purwaningsih (2009) yang menyatakan bahwa padi beras merah varietas Mandel menunjukkan nilai tertinggi untuk parameter tinggi tanaman.

Pada variabel total jumlah anakan dan jumlah anakan produktif, varietas Mandel Wonogiri memiliki rata-rata paling rendah dibanding varietas lain. Tetapi hasil analisis DMRT menunjukkan bahwa varietas Mandel Wonogiri tidak berbeda nyata dengan varietas Segreng Gunung Kidul, Segreng Boyolali, dan Segreng Wonogiri 1. Menurut BPTPY (2006), varietas Mandel dapat menghasilkan 7 anakan pada tanah alfisol. Sutardi, Kristamtini, dan Widyayanti (2011) juga menyatakan bahwa jumlah anakan produktif terendah dicapai oleh varietas Mandel Handayani.

Tabel 2. Rata-rata Variabel Pertumbuhan

\begin{tabular}{llll}
\hline \multirow{2}{*}{ Varietas } & \multicolumn{3}{c}{ Variabel Pertumbuhan } \\
\cline { 2 - 4 } & TT & TJA & JAP \\
\hline Mandel Wonogiri & $166,74 \mathrm{c}$ & $7,04 \mathrm{a}$ & $6,18 \mathrm{a}$ \\
Segreng Gunung Kidul & $127,54 \mathrm{ab}$ & $11,33 \mathrm{ab}$ & $10,67 \mathrm{ab}$ \\
Segreng Boyolali & $120,47 \mathrm{a}$ & $9,04 \mathrm{a}$ & $7,59 \mathrm{a}$ \\
Segreng Wonogiri 1 & $128,25 \mathrm{ab}$ & $17,11 \mathrm{~b}$ & $14,51 \mathrm{~b}$ \\
Segreng Wonogiri 2 & $136,89 \mathrm{~b}$ & $12,18 \mathrm{ab}$ & $11,39 \mathrm{ab}$ \\
\hline
\end{tabular}

Keterangan: TT = Tinggi Tanaman (cm); TJA = Total Jumlah Anakan (batang); JAP = Jumlah Anakan Produktif (batang). Angka pada kolom yang sama yang diikuti dengan huruf yang sama tidak berbeda nyata pada uji Duncan $5 \%$.

Tabel 2 menunjukkan bahwa varietas Mandel Wonogiri memiliki panjang malai dan jumlah gabah per malai paling tinggi. Hasil analisis DMRT menunjukkan, varietas Mandel Wonogiri berbeda nyata dengan varietas lain. Kristamtini dan Purwaningsih (2009) melaporkan bahwa tinggi tanaman varietas Mandel paling tinggi dan panjang malainya juga paling panjang dibanding varietas lain.

Varietas Segreng Wonogiri 1 memiliki rata-rata jumlah malai per rumpun paling tinggi tetapi tidak berbeda nyata dengan varietas Segreng Wonogiri 2 berdasarkan analisis DMRT. Yos Sutiyoso (1999) menyatakan bahwa tanaman yang cukup dalam melakukan proses fotosintesis akan memiliki perakaran yang berkembang baik, jumlah anakan yang banyak, serta membentuk malai yang banyak. Pada variabel berat 1000 biji, varietas Mandel Wonogiri menunjukkan hasil rata-rata paling rendah. Berdasarkan analisis varian, varietas tidak berpengaruh nyata terhadap variabel berat 1000 biji.

Varietas Segreng Wonogiri 1 memiliki rata-rata berat gabah per rumpun paling tinggi tetapi tidak berbeda nyata dengan varietas Segreng Gunung Kidul, Segreng Boyolali, dan Segreng Wonogiri 2 pada analisis DMRT. Hal utama yang mempengaruhi berat gabah yaitu ukuran dan bernasnya gabah. Berdasarkan penelitian Rizki (2012), bentuk dan ukuran gabah mempengaruhi bobot gabah yang dihasilkan.

Varietas Segreng Boyolali memiliki kadar antosianin paling tinggi, tetapi tidak berbeda nyata dengan varietas lain berdasarkan analisis DMRT. Berdasarkan gambar 1 dan gambar 2, gabah varietas Segreng Boyolali memiliki kulit lebih gelap dibanding varietas Segreng Wonogiri 1. Suliartini et al. (2011) menyatakan bahwa beras merah yang berkadar memiliki warna butiran beras yang lebih cerah.

Antosianin tinggi umumnya memiliki warna beras yang lebih gelap dan kadar antosianin rendah umumnya Padi varietas Segreng Gunung Kidul memiliki tinggi tanaman paling tinggi. Hal ini berakibat pada besarnya penerimaan sinar matahari. Antosianin akan terdegradasi apabila terkena suhu yang tinggi. Sistrunk dan Morris (1984) menyatakan bahwa penyebab utama kerusakan warna antosianin adalah perlakuan panas selama proses pengolahan.

\section{Korelasi Antar Sifat (Variabel)}

Hasli Analisis korelasi antar sifat (variabel), yakni tanaman, total jumlah anakan, jumlah anakan produktif, panjang malai, jumlah malai per rumpun, berat 1000 biji, berat gabah per malai, jumlah gabah per malai, dan kadar antosianin yang dinyatakan dalam koefisien korelasi fenotipe dan genotipe dapat dilihat pada Tabel 3. 
Tabel 3. Rata-rata Hasil, Komponen Hasil, dan Kandungan Antosianin

\begin{tabular}{lllllll}
\hline \multirow{2}{*}{ Varietas } & \multicolumn{5}{c}{ Variabel Hasil dan Komponen Hasil } \\
\cline { 2 - 7 } & PM & JMPR & BSB & BGPR & JGPM & ANT \\
\hline Mandel Wonogiri & $23,58 \mathrm{c}$ & $7,8 \mathrm{a}$ & 18,19 & $11,34 \mathrm{a}$ & $142,55 \mathrm{~b}$ & $0,00670 \mathrm{a}$ \\
Segreng Gunung Kidul & $19,02 \mathrm{a}$ & $11,2 \mathrm{~b}$ & 22,50 & $21,97 \mathrm{~b}$ & $86,08 \mathrm{a}$ & $0,00286 \mathrm{a}$ \\
Segreng Boyolali & $21,28 \mathrm{a}$ & $9,4 \mathrm{ab}$ & 20,36 & $15,95 \mathrm{ab}$ & $112,67 \mathrm{a}$ & $0,00706 \mathrm{a}$ \\
Segreng Wonogiri 1 & $19,55 \mathrm{~b}$ & $15,2 \mathrm{c}$ & 19,78 & $23,01 \mathrm{~b}$ & $102,62 \mathrm{a}$ & $0,00256 \mathrm{a}$ \\
Segreng Wonogiri 2 & $19,30 \mathrm{ab}$ & $12,2 \mathrm{bc}$ & 20,30 & $20,31 \mathrm{~b}$ & $100,83 \mathrm{a}$ & $0,00267 \mathrm{a}$
\end{tabular}

Keterangan : PM = Panjang Malai (cm); JMPR = Jumlah Malai per Rumpun (helai); BSB = Berat 1000 Biji (gram); BGPR = Berat Gabah per Rumpun (gram); JGPM = Jumlah Gabah per Malai (biji); ANT = Kadar Antosianin (\%). Angka pada kolom yang sama yang diikuti dengan huruf yang sama tidak berbeda nyata pada uji Duncan $5 \%$.

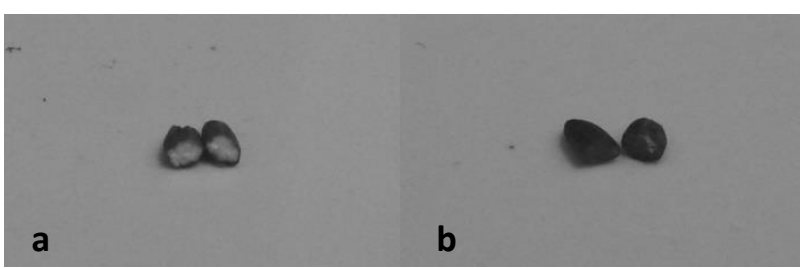

Gambar 1. Penampang beras merah varietas Segreng Wonogiri 1 (a) dan varietas Segreng Boyolali (b)

Koefisien korelasi antar karakter yang tidak signifikan menunjukkan bahwa antar karakter tersebut memiliki hubungan yang tidak erat. Hal ini terjadi pada korelasi antara tinggi tanaman dengan total jumlah anakan, jumlah anakan produktif, berat 1000 biji, dan berat gabah per rumpun. Korelasi antara total jumlah anakan dengan berat 1000 biji juga menunjukkan tidak signifikan.

Koefisien korelasi yang menunjukkan angka positif berarti peningkatan karakter yang satu akan diikuti oleh peningkatan karakter yang lain (berbanding lurus). Sebaliknya, koefisien korelasi negatif berarti peningkatan karakter yang satu akan menurunkan karakter yang lain (berbanding terbalik).

Tabel 4. Matrik Korelasi Fenotipe dan Genotipe Padi Beras Merah

\begin{tabular}{|c|c|c|c|c|c|c|c|c|c|c|}
\hline Sifat & Kor & $\mathrm{Tt}$ & Tja & Jap & $\mathrm{Pm}$ & Jmpr & Bsb & Bgpr & Jgpm & Anto \\
\hline \multirow{2}{*}{ TT } & $\mathrm{G}$ & \multirow{2}{*}{1} & $0.159 \mathrm{~ns}$ & $0.145 \mathrm{~ns}$ & $0.464^{*}$ & $-0.545^{\star}$ & $0.196 \mathrm{~ns}$ & $0.226 \mathrm{~ns}$ & $0.492^{*}$ & $-0.657^{*}$ \\
\hline & $F$ & & $0.155 \mathrm{~ns}$ & $0.140 \mathrm{~ns}$ & $0.451^{*}$ & $-0.535^{\star}$ & $0.194 \mathrm{~ns}$ & $0.223 \mathrm{~ns}$ & $0.454^{*}$ & $-0.651^{*}$ \\
\hline \multirow{2}{*}{ TJA } & $\mathrm{G}$ & & \multirow{4}{*}{1} & $0.880^{*}$ & $0.519^{*}$ & $0.641^{*}$ & $0.219 \mathrm{~ns}$ & $0.988^{*}$ & $0.497^{*}$ & $0.486^{\star}$ \\
\hline & $\mathrm{F}$ & & & $0.797^{\star}$ & $0.516^{*}$ & $0.638^{*}$ & $0.189 \mathrm{~ns}$ & $0.905^{\star}$ & $0.470^{*}$ & $0.482^{*}$ \\
\hline \multirow{2}{*}{ JAP } & $\mathrm{G}$ & & & \multirow{4}{*}{1} & $0.430^{*}$ & $0.672^{*}$ & $0.441^{*}$ & $0.438^{*}$ & $0.469^{*}$ & $0.481^{*}$ \\
\hline & $\mathrm{F}$ & & & & $0.412^{*}$ & $0.670^{*}$ & $0.437^{\star}$ & $0.430^{\star}$ & $0.409^{*}$ & $0.454^{\star}$ \\
\hline \multirow{2}{*}{ PM } & $\mathrm{G}$ & & & & \multirow{4}{*}{1} & $-0.431^{*}$ & $0.705^{\star}$ & $0.667^{*}$ & $0.818^{*}$ & $0.415^{\star}$ \\
\hline & $\mathrm{F}$ & & & & & $-0.420^{*}$ & $0.697^{\star}$ & $0.526^{*}$ & $0.804^{*}$ & $0.406^{\star}$ \\
\hline \multirow{2}{*}{ JMPR } & G & & & & & \multirow{2}{*}{1} & $0.446^{\star}$ & $0.573^{\star}$ & $0.489^{*}$ & $0.549^{\star}$ \\
\hline & $\mathrm{F}$ & & & & & & $0.441^{*}$ & $0.517^{*}$ & $0.435^{*}$ & $0.535^{*}$ \\
\hline \multirow[b]{2}{*}{ BSB } & $G$ & & & & & & \multirow{2}{*}{1} & $0.491^{*}$ & $0.572^{*}$ & $0.584^{\star}$ \\
\hline & $\mathrm{F}$ & & & & & & & $0.434^{*}$ & $0.566^{*}$ & $0.557^{\star}$ \\
\hline \multirow{2}{*}{ BGPR } & $\mathrm{G}$ & & & & & & & \multirow{4}{*}{1} & $0.661^{*}$ & $0.499^{*}$ \\
\hline & $\mathrm{F}$ & & & & & & & & $0.613^{*}$ & $0.495^{\star}$ \\
\hline \multirow{2}{*}{ JGPM } & G & & & & & & & & \multirow{2}{*}{1} & $0.498^{\star}$ \\
\hline & $F$ & & & & & & & & & $0.485^{\star}$ \\
\hline ANTO & $\begin{array}{l}G \\
F\end{array}$ & & & & & & & & & 1 \\
\hline
\end{tabular}

Keterangan : $\mathrm{KOR}=$ Korelasi. Nilai horizontal menunjukkan koefisien korelasi $(\mathrm{G}=$ Genotipe dan $\mathrm{F}=$ Fenotipe $) .{ }^{*}=$ probabilitas nyata $(p<5 \%) . n s=$ probabilitas tidak nyata $(p>5 \%)$. TT $=$ Tinggi tanaman, JAP $=$ Jumlah anakan produktif, BGPR $=$ Berat gabah per rumpun, $\mathrm{BSB}=$ Berat $1000 \mathrm{biji}, \mathrm{JGPM}=$ Jumlah gabah per malai, $\mathrm{PM}=$ Panjang malai, $\mathrm{TJA}=$ Total jumlah anakan, JMPR = Jumlah malai per rumpun, $\mathrm{ANTO}=$ Antosianin.

Koefisien korelasi yang menunjukkan angka besar mendekati +1 atau -1 dapat digunakan sebagai dasar kriteria seleksi. Hal ini karena koefisien korelasi yang menunjukkan angka besar, berarti memiliki hubungan yang erat antar karakter yang diamati. Koefisien korelasi yang menunjukkan angka besar mendekati \pm 1 
yaitu total jumlah anakan dengan jumlah anakan produktif, dengan koefisien korelasi genotipe sebesar $0,880^{*}$ dan fenotipe sebesar $0,797^{*}$. Korelasi antara panjang malai dengan berat 1000 biji, dengan koefisien korelasi genotipe sebesar $0,705^{\star}$ dan fenotipe sebesar $0,697^{\star}$. Total jumlah anakan dengan berat gabah per rumpun dengan koefisien korelasi genotipe sebesar $0,988^{*}$ dan fenotipe sebesar $0,905^{*}$. Korelasi antara panjang malai dengan jumlah gabah per rumpun, dengan koefisien korelasi genotipe sebesar $0,818^{*}$ dan fenotipe sebesar $0,804^{*}$.

Tabel 4 menunjukkan bahwa koefisien korelasi genotipe lebih tinggi dari koefisien korelasi fenotipe. Selain itu, koefisien genotipe selalu searah dengan nilai koefisien fenotipe. Hal ini sesuai dengan penelitian Aryana (2009), nilai koefisien korelasi genotipe lebih besar dibandingkan dengan koefisien korelasi fenotipik, dan koefisien korelasi genotipik searah dengan nilai koefisien korelasi fenotipik. Koefisien korelasi yang searah dapat memudahkan dalam menentukan suatu karakter yang akan diseleksi berdasarkan karakter morfologinya (fenotipenya).

\section{KESIMPULAN DAN SARAN}

Secara umum, semua varietas yang diuji menunjukkan potensi hasil dan kandungan antosianin yang tidak berbeda, kecuali varietas Segreng Gunung Kidul memiliki hasil yang rendah dan Segreng Boyolali serta Mandel Wonogiri memiliki kandungan antosianin relatif tinggi. Karakter total jumlah anakan, panjang malai, dan jumlah malai per rumpun menunjukkan koefisien korelasi yang tinggi dengan hasil sehingga ketiga karakter tersebut dapat dijadikan sebagai kriteria seleksi untuk mendapatkan tanaman dengan potensi hasil tinggi. Semua karakter agronomi berkorelasi dengan kandungan antosianin, akan tetapi karakter tinggi tanaman, jumlah malai per rumpun, dan berat 1000 biji menunjukkan nilai koefisien korelasi yang tinggi dengan kandungan antosianin, sehingga ketiga karakter tersebut dapat digunakan sebagai dasar kriteria seleksi padi beras merah dengan kandungan antosianin yang tinggi.

\section{DAFTAR PUSTAKA}

formation and increase antioxidant in rabbits. $J$ Nutr 131(5): 1421-1426.

Maekawa M. 1998. Recent information on anthocyanin pigmentation. Rice Genetics Newsletter 13: 25-26.

Musa MS. 1978. Ciri kestatistikan beberapa sifat agronomi suatu bahan kegenitikan kedelai Glycine max I. Merr. Disertasi Doktor. Bogor (ID): IPB. 97h.

Perera AS, Jansz ER, 2000. Preliminary investigation on the red pigment in rice and its effect on glucose release from rice starch, J Nat Sci Found Sri Lanka 28(3): 185-192.

Rizki YN. 2012. Uji daya hasil pendahuluan galurgalur padi beras merah dan hitam hasil kultur antera. Departemen Agronomi dan Hortikultura
Aryana IGP Muliarta. 2009. Korelasi fenotipik, genotipik dan sidik lintas serta implikasinya pada seleksi padi beras merah. J Crop Agro 2(1).

Balai Penelitian Tanaman Pangan [BPTP] Yogyakarta. Departemen Pertanian. 2006. Beras merah. LIPTAN.

Chang TT, Bardenas EA. 1965. The morphology and varietal characteristics of the rice plant. Tech. Bull. IRRI 4: $40 \mathrm{pp}$.

Fitriani V. 2006. Beras merah bukan kenyang tapi sehat. http://www.Trubus.co.id. (Diakses pada tanggal 10 Agustus 2014).

Gealy DR, Bryant RJ. 2009. Seed physicochemical characteristics of field-grown us weedy rice (oryza sativa) biotypes: Contrasts with Commercial Cultivars. J Cereal Sci 49: 239-245.

Gepts P, Hancock J. 2006. The future of plant breeding. J Crop Sci 46: 1630-1634.

Giusti MM, Wrolstad RE. 2001. Characterization and measurement of antocyanins by uv-visible spectroscopy. Oregon State University. Available online at: http://does.org/masterli/facsample.htm37k. diakses 6 November 2013.

Heinemann RJB, Xu Z, Godber JS, Lanfer-Marquez UM. 2005. Comparative study of nutrient composition of commercial brown, parboiled and milled rice from Brazil. J Food Comp Analysis 18: 287-296.

Kristamtini, Purwaningsih H. 2009. Potensi pengembangan beras merah sebagai plasma nutfah. Yogyakarta. J Litbang Pert 28(3): 1-2.

Khush GS. 1995. Modern varieties - their realcontribution to food supply and equity. J Geo 35(3): 275-284.

Khush GS. 1999. Breaking yield frontier of rice. J Geo 35: 329-332.

Khush GS, Coffman WR, Beachell HM. 2001. The history of rice breeding. IRRI's contribution. In Rice Research and Production in the 21st Century. W.G. Rockwood (Ed.). IRRI, Los Banos, Philippines. p. 117-135.

Ling WH, Cheng QX, Ma J, Wang T. 2001. Red and black rice decrease atheros-clerotic plaque Fakultas Pertanian Institut Pertanian Bogor. (tidak dipublikasikan).

Singh RK, Chaudary BD. 1979. Biometrical methods in quantitative genetic analysis. New Delhi (IN). Kalyani Publishers. $304 p$.

Sistrunk WA, Morris JR, Junek J, Sims CA. 1986. Effects of fruit maturity, juice storage, and juice extraction temperature on quality of 'concord' grape juice. J Amer Soc Hort Sci 111(5): 742-746.

Suda I, Oki T, Masuda M, Kobayashi M, Nishiba Y, Furuta S. 2003. Physiologycal functionality of purple-fleshed sweet potatoes containing anthocyanins and their utilization in food. J ARQ 37(3): 167-173. 
Agrosains 16(2): 49-54, 2014; ISSN: 1411-5786

Suliartini NWS, Sadimantara GR, Wijayanto T, Muhidin. 2011. Pengujian kadar antosianin padi gogo beras merah hasil koleksi plasma nutfah sulawesi tenggara. J Crop Agro 4(2): 43-48.

Sutardi, Kristamtini, Widyayanti S. 2011. Seleksi potensi hasil beberapa galur harapan padi gogo di desa Sidomulyo Kabupaten Kulon Progo.
Yogyakarta (ID): Balai Pengkajian Teknologi Pertanian.

Xia X, Ling W, Ma J, Xia M. 2006. An anthocyanin-rich extract from black rice enhances atherosclerotic plaque stabilization in apolipoprotein e-deficient mice. J Nutri 136: 2220-2225.

Yos S. 1999. Pedoman menanam anggrek. Jakarta (ID): P.D. Putra Kencana. 